\title{
XANTHOGRANULOMATOUS PYELONEPHRITIS IN A TETRAPLEGIC PATIENT
}

\author{
By John B. Nanninga, M.D., and Vincent J. O’Conor, JR., M.D. \\ Chicago Wesley Memorial Hospital, and the Rehabilitation Institute of \\ Chicago, and Northwestern University Medical Center, Chicago, \\ Illinois 606I I, U.S.A.
}

XanthogRanulomatous pyelonephritis represents a severe and unusual form of renal parenchymal infection. In this disease the normal kidney is replaced by a yellow nodular infiltrate which may easily be confused with tuberculosis or renal carcinoma. This difficulty of recognition is evident in the cases reported by Hooper, Kempson and Schlegel (1962) and Selzer (1957). Microscopically, the areas of xanthogranulomatous replacement, described by Saeed and Fine (I963), show macrophages containing foamy cytoplasm composed of lipid and cholesterol. These lipid-filled cells have been termed foam cells by Barrie (1949).

The first description of xanthogranulomatous pyelonephritis was probably by Schlagenhaufer in 19I6. Putschar (1934) described the yellow xanthomatous appearance which may be confused with renal neoplasms or tuberculosis. In I966 Rios-Dalenz reported that there were 67 cases in the literature. Among these was the occurrence of xanthogranulomatous pyelonephritis in a paraplegic reported in the series by Hooper (1962). In I967 Kawaichi and Reingold reported the occurrence of xanthogranulomatous pyelonephritis in three kidneys out of I9 removed at the Long Beach Veterans Hospital on the Spinal Cord Injury Section. Tribe and Silver (1969) mentions xanthogranuloma formation occurring in the kidneys of paraplegic patients. The purpose of this communication is to report the occurrence of xanthogranulomatous pyelonephritis in a male tetraplegic and emphasise certain principles in the management of this lesion.

Case Report. A 2I-year-old male tetraplegic was admitted to the urology service with a 3-week history of an asymptomatic urinary tract infection which had been refractory to antibiotic therapy. He was known to have had a calculus in the right kidney for two years but the kidney had displayed relatively normal function by excretory urography at that time. An excretory urogram during the current admission revealed the stone in the right kidney but there was no demonstrable function on the right (figs. I and 2). A radioisotope renogram and renal scan also failed to demonstrate function of the right kidney. Cystoscopy was performed and a right pyeloureterogram confirmed the presence of an obstructing calculus in the renal pelvis. The patient subsequently underwent exploration of the kidney. Upon opening the perirenal fascia purulent material was encountered and when the surface of the kidney was exposed cortical scars and replacement of normal parenchyma with yellow nodular tissue was noted. Because of the lack of demonstrable function in the kidney and the extent of gross infection and parenchymal destruction there seemed little chance of salvagability and the kidney was therefore removed. Post-operatively the patient's recovery was uneventful. He did drain purulent material from the incisional drains for about two weeks, but this finally ceased. Cultures from the urine and the specimen revealed Proteus vulgaris and the infection responded to Kanamycin therapy. Grossly the kidney contained calculi and massive parenchymal 


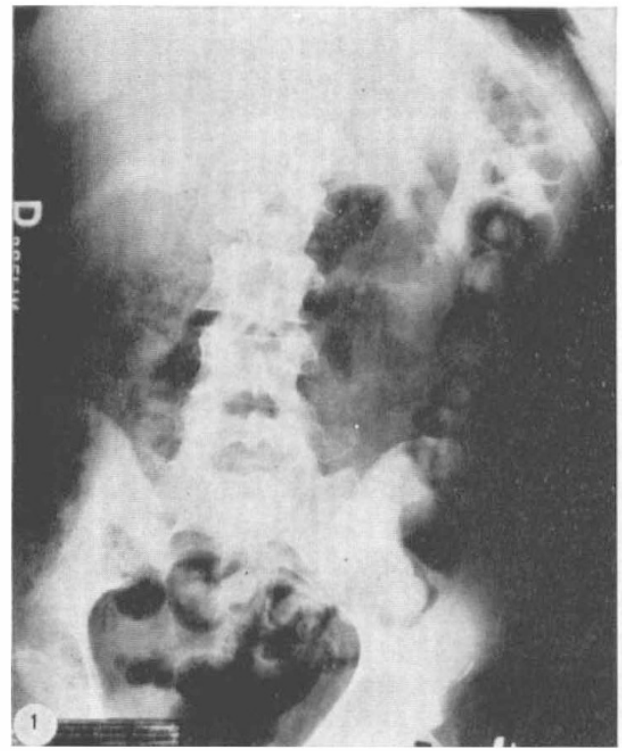

FIG. I

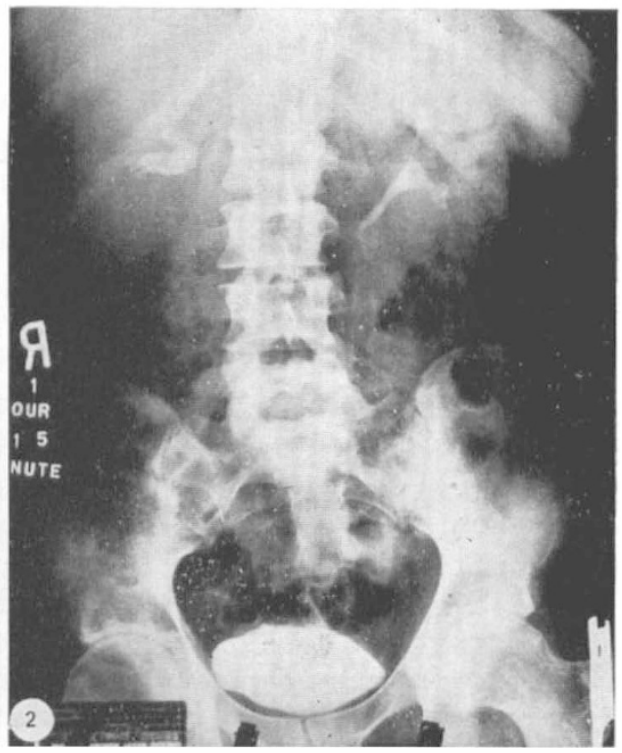

FIG. 2

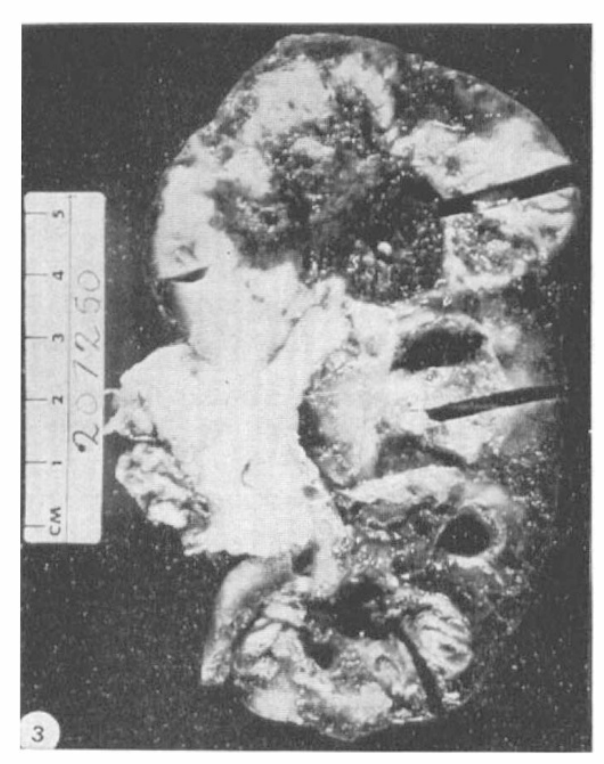

FIG. 3

Fig. 1.-Preliminary film showing calculus in right kidney.

Fig. 2.-Excretory urogram demonstrating absence of function on the right.

Fig. 3.-Gross specimen demonstrating the marked yellow-white xanthogranulomatous replacement.

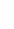

involvement with yellow tissue (fig. 3). The histological sections revealed the characteristic foam cell of xanthogranulomatous pyelonephritis along with scattered leukocytes (figs. 4 and 5). The extent of the destruction undoubtedly accounted for the failure of the kidney to function on the excretory urogram and the isotope studies. 


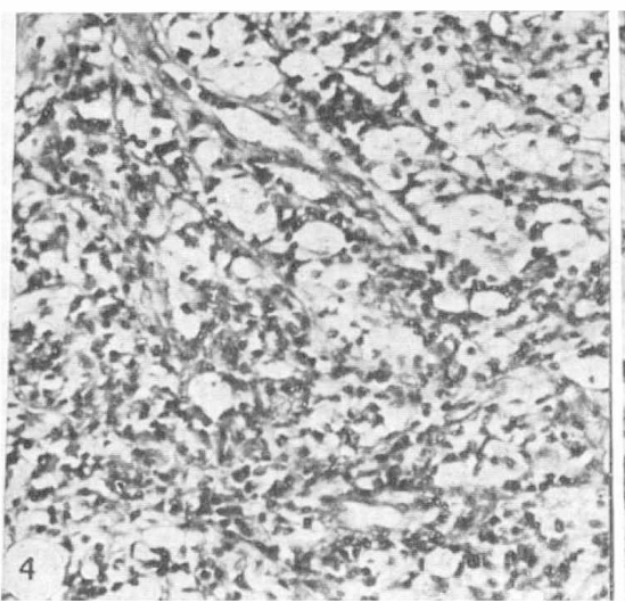

FIG. 4

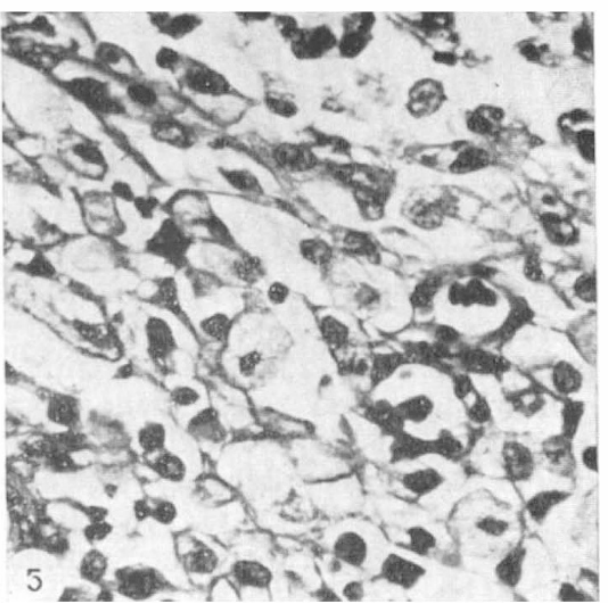

FIG. 5

Fig. 4.-Microscopic section demonstrating typical foam cell infiltrate of xanthogranulomatous pyelonephritis.

Fig. 5.-High-power section showing the foam cells.

\section{DISCUSSION}

The etiology of xanthogranulomatous pyelonephritis is uncertain. Contributing factors which were evident in this patient as well as those in the patients reported by Hooper (1962), Kawaichi (1967) and Friedenberg and Spjut (1963) include obstruction and infection. Proteus has been associated with many of the reports of xanthogranulomatous pyelonephritis; however, other bacteria have been found suggesting that one particular organism is not the causative agent. The histological appearance has been attributed by Barrie (1949) to the formation of foam cells from fibroblasts in response to infection. Smout, McAnich and Wyatt (1963) maintains that the fat released from damaged cells is phagocytised by histiocytes, thus giving the typical appearance of xanthogranulomatous pyelonephritis. RiosDalenz proposes that disturbed lipid metabolism or lipids accumulating from cell injury caused by an insult such as obstruction and infection could give rise to the foam cells. Recently experimental work in rats suggests that obstruction and the presence of bacteria lend to xanthogranulomatous pyelonephritis (Povysil \& Konickova, 1972).

Symptoms of this disease are often referable to the affected side and consist of flank pain, chills and malaise as well as frequency and dysuria associated with urinary infection. However, the course may be indolent and there have often been symptoms for several months before the diagnosis is made. In the spinal cord injury patients reported by Kawaichi and Reingold (1967) pain and tenderness were not significant because of the level of injury. Similarly, the patient reported herein had no specific symptoms.

The most suggestive findings of xanthogranulomatous pyelonephritis seem to be the presence of a urinary tract infection associated with a non-functioning kidney and an obstructing lesion such as a calculus. However, Hooper (I962), Butnick (I97I) and Souto, Monteiro and Andrade (I969) have reported patients in whom some function was noted on the urogram. Arteriography has been reported 
in cases of xanthogranulomatous pyelonephritis by Becker (1966), Souto (I969) and Butnick (I97I). The arteriograms tended to show only a relatively avascular lesion with no definite diagnostic sign. In most patients, therefore, the diagnosis will most likely be made by the surgeon at the operating table and the pathologist. The decision as to whether a kidney with xanthogranulomatous involvement should be removed would seem to be based on demonstrable presence or absence of function and the gross extent of xanthogranulomatous replacement. Of course, in many instances, the lesion is mistaken for neoplasm and for this reason nephrectomy is performed. We are not aware of any reports of functional improvement in a kidney with xanthogranulomatous pyelonephritis. Probably xanthogranulomatous replacement indicates complete and irreversible destruction. Birkeland (I97I) has reported exploring a kidney thought to contain a tumor and biopsying it after it appeared unresectable. The biopsy revealed xanthogranuloma. This patient was followed for $\mathrm{I} \frac{1}{2}$ years, but no mention was made as to the return of function. This patient's urine continued to be infected and this would seem a reasonable indication for nephrectomy. This disease should not be confused with an infected hydronephrosis or pyelonephrosis since such kidneys, without xanthogranulomatous changes, may resume satisfactory function following surgical intervention (Walsh, 1970).

\section{SUMMARY}

A tetraplegic patient with xanthogranulomatous pyelonephritis is presented. The presence of an obstructing renal calculus, infection and non-visualisation on the excretory urogram were findings which are similar to others reported in the literature and suggest the diagnosis. Nephrectomy seems to be the treatment of choice because of the severe renal destruction associated with the infection.

\section{ZUSAMMENFASSUNG}

Ein Tetraplegiker mit xanthogranulomatöser Pyelonephritis wird beschrieben. Obstruktiver Nierenstein, Infektion und negatives exkretorisches Urogramm waren die Befunde, ähnlich mit andern in der Literatur beschriebenen und hinweisend für die Diagnose. Nephrektomie seheint die Methode der Wahl für die Therapie zu sein mit Rücksicht auf renale Zerstörung und Infektion.

\section{REFERENCES}

BARrie, H. J. (1949). Brit. F. Surg. 36, 3 I6.

BECKER, J. A. (I966). Acta Radiol. (Diagn.) 4, I39.

Birkeland, S. A. (I97I). Scand. F. Urol. Nephrol. 5, 285.

ButNick, R. (I97I). F. Urol. 106, 815.

FRIEDENBERG, M. J. \& SPJUT, H. J. (I963). Am. F. Roent. 90, 97.

Hooper, R. G., Kempson, R. L. \& SChlegel, J. U. (I962). F. Urol. 88, 585.

KAWAichi, G. K. \& ReINGOld, I. M. (I967). F. Urol. 97, 58.

Povysil, C. \& Konickova, L. (I972). Invest Urol. 9, 313.

Putschar, W. (1934). Handbuch der Spez Path. Anat. Hist., ed. S. Henke \& O. Lubarsch, Vol. 6, p. 333. Berlin: Springer.

Rios-Dalenz, J. L. \& PeAcock, R. C. (I966). Cancer, 19, 289.

SaeEd, S. M. \& Fine, G. (1963). Am. F. Clin. Path. 39, 6 I6.

Schlagenhaufer, F. (I9I6). Frankfurt Z. Path. 19, I39.

Selzer, D. W., Dahlin, D. C. \& DeWeERD, J. H. (I957). Surgery, 42, 874.

Smout, M. S., MCANICH, L. N. \& Wyatt, J. K. (I963). Brit. F. Urol. 35, I29.

Souto, C. A. V., Monteiro, S. H. \& ANdrade, L. C. (I969). F. Urol. 102, 393.

Tribe, C. R. \& Silver, J. R. (1969). Renal Failure in Paraplegia. Baltimore: Williams \& Wilkins.

Walsh, J. J. (1970). Int. F. Paraplegia, 8, I2I. 